\title{
THE PROTECTION OF CIVIL AND POLITICAL RIGHTS BY THE CONSTITUTIONAL COURT OF INDONESIA
}

\author{
Pan Mohamad Faiz*
}

\begin{abstract}
*TC Beirne School of Law, the University of Queensland, The University of Queensland, St. Lucia Campus, Australia
\end{abstract}

\author{
Article Info \\ Received : 31 March 2016 | Received in revised form : 8 June 2016 | Accepted : 16 August 2016 \\ Corresponding author's e-mail : pan.mohamad.faiz@gmail.com
}

\begin{abstract}
One of important mechanisms considered effective to protect civil and political rights of the citizens in Indonesia is constitutional review. This mechanism was created after the constitutional reform by establishing the new Constitutional Court in 2003 as an independent and separate court from the Supreme Court. This article examines the development of human rights guaranteed in the Indonesian Constitution. It also provides a critical analysis of the Constitutional Court's role in protecting civil and political rights in Indonesia through its landmark decisions on five categories, namely: (1) freedom of assembly and association; (2) freedom of opinion, speech and expression; (3) freedom of religion; (4) right to life; and (5) due process of law. This research was conducted based on qualitative research methodology. It used a non-doctrinal approach by researching the socio-political impacts of the Constitutional Court's decisions. Although there are still inconsistencies in its decisions, the research concludes that the Constitutional Court has taken a step forward for a better protection of civil and political rights in Indonesia that never existed prior to the reform.
\end{abstract}

Keywords: civil and political rights, constitutional court, human rights, Indonesia

\begin{abstract}
Abstrak
Salah satu mekanisme yang dianggap efektif untuk melindungi hak sipil dan politik warga negara di Indonesia adalah pengujian konstitusional. Mekanisme ini dibentuk pasca reformasi konstitusi dengan mendirikan Mahkamah Konstitusi pada 2003 sebagai peradilan yang independen dan terpisah dari Mahkamah Agung. Artikel ini menganalisa perkembangan hak asasi manusia yang dijamin di dalam UUD 1945. Selain itu, artikel ini juga memberikan analisa kritis terhadap peran Mahkamah Konstitusi dalam perlindungan hak sipil dan politik di Indonesia melalui putusan-putusan pentingnya (landmark decisions) pada lima kategori, yaitu: (1) kebebasan untuk bekumpul dan berserikat; (2) kebebasan berpendapat, berbicara, dan berekspresi; (3) kebebasan beragama; (4) hak untuk hidup; dan (5) proses peradilan yang adil. Penelitian ini dilakukan berdasarkan pada metodologi penelitian kualitatif dan menggunakan pendekatan non-doktrinal dengan meneliti dampak sosio-politik dari putusan-putusan Mahkamah Konstitusi. Meskipun masih terdapat inkonsistensi di dalam putusannya, penelitian ini menyimpulkan bahwa Mahkamah Konstitusi telah memberikan kontribusi satu langkah ke depan yang lebih baik terhadap perlindungan hak sipil dan politik di Indonesia yang tidak pernah terjadi sebelum era reformasi.
\end{abstract}

Kata Kunci: hak asasi manusia, hak sipil dan politik, mahkamah konstitusi, Indonesia 


\section{Introduction}

The protection of fundamental rights and freedoms is an important element of constitutional goverment because it can develop the personality of individual citizens and the advancement of human welfare in a democratic system. The protection can be started by incorporating a list of human rights into the constitution of a country. The amended Indonesian Constitution has a special chapter on human rights that provides almost all rights contained in the Universal Declaration of Human Rights (UDHR), also referred to as the Constitutional Bill of Rights.

However, if there is a list of human rights in the Constitution, but it does not provide a mechanism to enforce those provisions, it cannot automatically be concluded that the country has a constitutional government. Even where there are established mechanisms, constitutional government might fail because, in practice, the constitutional forms and processes are not observed or they are actively subverted by those whose responsibility is to uphold the constitution.

In order to protect the human rights, particularly civil and political rights, the $2^{\text {nd }}$ generation of founding fathers, who amended the Indonesian Constitution from 1999-2002, established the Constitutional Court as a separate and independent court from the Supreme Court. The Constitutional Court's main jurisdiction is to review the constitutionality of law (undang-undang). ${ }^{1}$ In addition to the jurisdiction for conducting constitutional review, the Indonesian Constitutional Court has other jurisdictions, which include: determining disputes concerning the authorities of the state institutions whose powers are derived from the constitution; deciding matters concerning the dissolution of a political party; and deciding disputes over the result of general elections. ${ }^{2}$

The Court also has a jurisdiction to make a decision concerning the opinion of the House of Representatives (Dewan Perwakilan Rakyat, or DPR) about alleged violations of the Constitution by the President or the Vice President. In other words, it has the power to make the final decision in legal matters for any impeachment process of the President or the Vice President. ${ }^{3}$

Since its official establishment on 13 August 2003 until 13 August 2015, the Constitutional Court decided 1,649 cases. These decisions are divided into 762 decisions concerning constitutional review, 24 decisions concerning cases on disputes between state institutions, and 863 decisions concerning electoral cases. ${ }^{4}$ The case statistics of constitutional review in the Indonesian Constitutional Court can be seen on the figure below.

${ }^{1}$ Debates among Parliament members during the process of establishment of the Constitutional Court, see Mahkamah Konstitusi Republik Indonesia, Naskah Komprehensif Perubahan Undang-Undang Dasar Negara Republik Indonesia Tahun 1945 [Comprehensive Draft on Amendment of the 1945 Constitution of Republic Indonesia] (Jakarta: Sekretaris Jenderal dan Kepaniteraan MKRI, 2010), vol 6, ch 5.

2 Indonesia, Undang-Undang Dasar Negara Republik Indonesia Tahun 1945 (Indonesian Constitution of 1945), art. 24C(1).

${ }^{3}$ Ibid., art. 24C(2).

4 Mahkamah Konstitusi Republik Indonesia, “Rekapitulasi Perkara," [“Case recapitulation”], http:// www.mahkamahkonstitusi.go. id/index.php?page=web.Beranda, accessed 10 November 2015. 


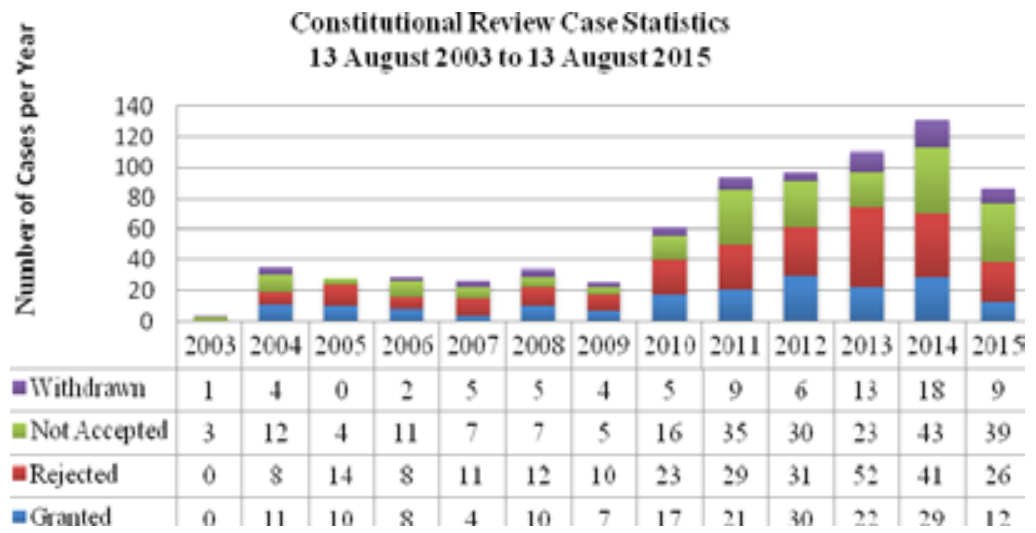

Source: The Indonesian Constitutional Court

Figure 1: Constitutional Review Case Statistics

The question is: how does the Constitutional Court play a role in protecting civil and political rights of citizens in Indonesia? This article will analyse the influences and implications of the landmark decisions of the Constitutional Court in protecting civil and political rights in Indonesia. ${ }^{5}$ However, not all decisions made by the Constitutional Court can be categorised as landmark decisions. The criteria of landmark decision are given to the decisions that create an important new legal principle, concept or constitutional interpretation that affects the existing law and legal system. ${ }^{6}$ Therefore, the landmark decisions discussed in this article were chosen by analysing selected important decisions of constitutional review published by the Constitutional Court in its official reports annually.

Moreover, while this topic lends itself to extensive discussion, the scope of this discussion will also be limited to the analysis of landmark decisions on five specific categories: (1) freedom of assembly and association; (2) freedom of opinion, speech and expression; (3) freedom of religion; (4) right to life; and (5) due process of law. To achieve valid outcomes, this research is conducted based on qualitative research methodology by examining primary and secondary sources, particularly case laws. ${ }^{7}$ It also used a non-doctrinal research methodology to understand the law as a social phenomenon by researching the socio-political impacts of the Constitutional Court's decisions. ${ }^{8}$ This article begins by discussing the development of human rights in the Indonesian Constitution.

\footnotetext{
${ }^{5}$ See International Covenant on Civil and Political Rights (ICCPR) which was adopted and opened for signature, ratification and accession by General Assembly resolution 2200A (XXI) on 16 December 1966; Sarah Joseph and Melissa Castan, The International Covenant on Civil and Political Rights: Cases, Materials, and Commentary (Oxford: Oxford University Press, 2013).

6 According to Black's Law Dictionary, landmark decision is "a judicial decision that significantly changes existing law". See Bryan A. Garner, Black's Law Dictionary, ninth edition (St. Paul, MN: Thomson Reuters), p. 957.

${ }^{7}$ Ian Dobinson and Francis Johns, "Qualitative Legal Research" in Research Methods for Law, edited by Mike McConvile and Wing Hong Chui (Edinburg University Press, 2007), p. 17; See also Peter Halfpenny, "The Analysis of Qualitative Data" The Sociological Review Vol. 27 Issue 4 (1979): 799-827.

8 Terry Hutchinson, Researching and Writing in Law (New South Wales: Lawbook, 2010), pp. 7-8; Ann Majchrzak, Methods for Policy Research (Thousand Oaks, CA: Sage Publications, 1984) 24.
} 


\section{Human Rights in the Indonesian Constitution}

The idea to include human rights in the original 1945 Constitution was discussed by the framers of the Constitution. However, some founding fathers opposed and rejected the concept of rights and freedoms, which were considered a reflection of western individualistic and liberal views, closely related to colonialism and imperialism at that time. According to Soekarno and Soepomo, two leading national leaders at that time, the Indonesian Constitution should be based on the family principlct (asas kekeluargaan), entirely contrary to the principle of liberalism and individualism. ${ }^{9}$ Although Muhammad Hatta and Muhammad Yamin agreed with the familt principle, they still proposed that some rights and freedoms be incorporated into the 1945 Constitution to ensure that the citizens would not be afraid of expressing opinions and peaceful assembly, as well as to prevent the state from becoming a rule of power state. ${ }^{10}$ Sharp debate among the founding fathers led to a compromise that included only seven provisions related human rights in the 1945 Constitution declared on 18 August 1945, a day after the Indonesian Independence.

Furthermore, based on the results of the Round Table Conferencn among the representatives of the Republic of Indonesia, the Netherlands and the United Nations on 2 November 1949, the Netherlands agreed to transfer Indonesian sovereignty to the Republic of the United States of Indonesia (Republik Indonesia Serikat, or RIS), a new system of government. Consequently, the 1945 Constitution was replaced by a new constitution named the Constitution of the Republic of the United States of Indonesia (the RIS Constitution) on 27 December 1949. The RIS Constitution was heavily influenced by the Universal Declaration of Human Rights (UDHR,; declared on 10 December 1945. Therefore, the RIS Constitution, consisting of 197 articles, provided all the provisions on human rights contained in the UDHR. Thus, Indonesia became one of the first countries to comprehensively incorporate a guarantee of rights and freedoms in their Constitution. ${ }^{11}$

Eight months later, the 1950 Provisional Constitution replaced the RIS Constitution on the grounds that the RIS Constitution was created based on foreign pressures and influences and not by a special Assembly representing the interests of Indonesian citizens. Also, the federal system was considered incompatible and inconsistent with the principles of the declaration of Indonesian independence, intended to establish the Unitary State of the Republic of Indonesia (Negara Kesatuan Republik Indonesia, or NKRI). The 1950 Provisional Constitution was drafted by a joint committee consisting of the Working Committee of the Central National Committee, the House of Representatives and the Senate of the Republic of the United States of Indonesia. ${ }^{12}$ The word 'Provisional' implies that Indonesia at that time needed a new and permanent Constitution that would be made by the Constituent Assembly..$^{13}$ The 1950 Provisional Constitution, which consists of 146 articles, also contained guarantees of rights and

\footnotetext{
${ }^{9}$ Soekarno, who later became the first President of the Republic of Indonesia, referred 'the right of the citizen' as enshrined in the Republic of France as one of examples for the concept of individualism.

10 Discussion concerning the debate in the drafting of the first Indonesian Constitution, see Muhammad Yamin, Naskah Persiapan Undang-Undang Dasar 1945, [Preparatory Draft of the 1945 Constitution] (Jakarta: Prapanjta, 1959).

11 Jimly Asshiddiqie, The Constitutional Law of Indonesia (Petaling Jaya: Sweet \& Maxwell Asia, 2009), pp. 502-512.

12 Ibid.

13 Article 134 of the 1950 Provisional Constitution provides, "Constitutional Assembly (Session of Framers of the Constitution) together with the government immediately set the Constitution of the Republic of Indonesia that will replace this Provisional Constitution."
} 
freedoms, which were almost the same as the RIS Constitution. These guarantees were contained in two parts: (1) Part V concerning Basic Rights and Freedoms of Human Beings from Article 7 to Article 34; and (2) Part VI concerning Basic Principles from Article 35 to Article 43.

Unfortunately, the Constituent Assembly, based on the results of the 1955 General Elections, did not succeed in making a new permanent Constitution. A deadlock ensued when they had to decide a crucial and sensitive issue concerning the relationship between state and religion, particularly in deciding the system of the state. Given that the Assembly could not reach an agreement on the draft of a new Constitution, ${ }^{14}$ President Soekarno established the Presidential Decree of 5 July 1959 (Dekrit Presiden 5 Juli). ${ }^{15}$ There were three major decisions in the Presidential Decree of 1959: First, dissolving the Constitutional Assembly; Second, re-enacting the original 1945 Constitution and repealing the 1950 Provisional Constitution; and Third, planning to establish a Provisional People's Consultative Assembly and the Provisional Supreme Advisory Council. Thus, the guarantee of rights and freedoms for Indonesian citizens reverted to the seven provisions contained in the 1945 Constitution, from 5 July 1959 until the New Order regime under President Soeharto (1966-1998). ${ }^{16}$

Furthermore, due to the economic crisis and human rights abuse di Indonesia, the fall of Soeharto's regime significantly impacted constitutional reform in Indonesia. The 1945 Constitution was amended for the first time in 1999, followed by four stages of amendments from 1999 to 2002. In 2000, the second amendmenofto the 1945 Constitution, guaranteeing human rights, was set up specifically in Chapter XA concerning Human Rights from Article 28A to Article 28J consisting 43 constitutional norms. It was created without amending the original seven provisions on guarantees of rights and freedoms as granted in the 1945 Constitution. These human rights are not only influenced by the UDHR, but also by various international conventions and international law instruments.

In addition to guaranteeing human rights, the Indonesian Constitution also stipulates an obligation of citizens to respect the human rights of others, as stated in Article 28J. Moreover, every person, in exercising their rights and freedoms, is limited by laws in accordance with considerations of morality, religious values, security and public order. This special constitutional provision provides the main difference between human rights recognised in Indonesia and those of other countries.

\section{III.Protection by the Constitutional Court}

The debate regarding the protection of human rights and its limitatios, often occurs before the Constitutional Court. This section will analyse the Constitutional

\footnotetext{
14 The Constitutional Assembly never reached the requirements for making decision based on Article 137(2) of the RIS Constitution which provides, "The new Constitution applies, if the draft has been accepted by at least two-thirds of votes from members who present and [it] is subsequently enacted by the Government."

${ }^{15}$ Indonesia, Presidential Decree No. 150 of 1959 concerning the Decree of the President of the Republic of Indonesia/Supreme Commander of the War Armed Forces on the Return to the 1945 Constitution.

${ }^{16}$ Based on the Resolution of the People's Consultative Assembly Number XIV/MPRS/1966, the Provisional People's Consultative Assembly formed the Ad-Hoc Committee and created a draft of the Charter of Human Rights and the Rights and Obligation of Citizens on 6 March 1967. Unfortunately, these results were not approved by the Assembly members to be incorporated into the 1945 Constitution. See Asshiddiqie, op.cit., pp. 633-634.
} 
Court's decisions affecting the protection of civil and political rights in Indonesia on five categories: (1) freedom of assembly and association; (2) freedom of opinion, speech and expression; (3) freedom of religion; (4) right to life; and (5) due process of law.

\section{A. Freedom of Assembly and Association}

Indonesian citizens started to enjoy freedom of assembly and association after the constitutional reform occurred in 1999. Prior to the reform era, the Government always curbed the freedom of assembly and association of its citizens. Presently, these freedoms are deemeo so excessive that they create negative impacts. Therefore, the government have bgaun to organize and limit the freedom of assembly and association according to law.

\section{Civic Organisation (2013) case}

The presence of thl Civic Organisation Law, enacted on 22 July 2013, sparked a controversy in Indonesia. ${ }^{17}$ The DPR and the President passed this law in order to strike a balance between the freedom of assembly and association and respect for rights and freedoms of others as well as to achieve legal order. Just two months after the law was enacted, the Muhammadiyah Association (Persyarikatan Muhammadiyah) filed a constitutional review against twenty-one Articles contained in thl Civic Organisation Law. In thl Civic Organisation (2013) case ${ }^{18}$ the applicant argued that the Law had stunted the meaning of freedom of association. According to this view, the government intervened too much in the practices of freedom of association, since the Law regulated excessive restrictions and did not provide legal certainty.

The Constitutional Court partially granted the request, citing four main legal reasons in its decision. First, the provision regulating that anl civic organisation shall have eight goals cumulatively, as mentioned in Article 5 of thl Civic Organisation Law, was deemed to violate the freedom of association. The Court ruled that the provision should be interpreted as merely alternative goals, not cumulative goals. Second, the Court found that the provisions, differentiating thl civic organisations in national, province or regional leves, would limit the development and activities of the organisation itself. Also, thl civic organisations cannot be obliged to register themselves with the government institution. While these organisations cannot be banned, they would not receive services from the state.

Third, the Court annulled the provision requiring every member ol civic organisations to have the same rights and obligations. The Court argued that it is an internal and autonomous matter of each organisation that should not be regulated by law. Fourth, the Court overturned the provisions regarding the role of government to undertake empowerment for thl civic organisations. According to the Court, this government's role can intervene in the freedom and independence of thl civic organisations. Therefore, assistanes given by the government tl civic organisations cannot be enforced; rather, acceptance depends upon each organisation. The Court reasoned that state intervention, while intended to empowel civic organisations,

\footnotetext{
${ }^{17}$ According to Article 1(1) of the Civic Organisation Law, "civic organisation" is defined as an organisation that is voluntarily founded and formed by the community based on shared aspirations, will, needs, interests, activities, and goals to participate in the development in order to achieve the purpose of the Unitary Republic of Indonesia based on Pancasila.

${ }_{18}$ Constitutional Court of Republic of Indonesia, “Decision No. 82/PUU-XI/2013.”
} 
would threaten expressions of creativity in their practice of freedom of assembly and association, as guaranteed by Article 28(3) of the Constitution. ${ }^{19}$

\section{Civic Organisation (2014) case}

Thl Civic Organisations Law was also reviewed by NGOs, such as the Indonesian Forum for Budget Transparency (FITRA), Indonesian Corruption Watch (ICW), YAPPIKA and other human rights activists in thl Civic Organisation (2014) case. ${ }^{20}$ The applicants challenged ten Articles in thl Civic Organisations Law, considered to have narrowed the scope of protection of the freedom of association. The Constitutional Court partially granted the petition. In its decision, the Court decided that the procedure of decision-making in the organisations should not be based only on a system of deliberation and consensus (musyawarah mufakat) according the Pancasila democracy, but also through a decision by majority votes. The Constitutional Court ruled that the imposition of decision-making systems, through deliberation and consensus according to thl Civic Organisations Law, would create legal uncertainty and injustice.

\section{Analysis}

The freedom of association and assembly is an absolute prerequisite to constitutional democracy and must be protected in the constitutional government system. Based on the two cases discussed above, however, the Indonesian government still has a tendency to restrict the freedom of association and assembly for its citizens. These prohibitions and restrictions on the freedom of assembly and association can threaten democratic values in a developing country like Indonesia. Thus, the role of the Indonesian Constitutional Court, on this issue, is very strategic in interpreting and reviewing laws and regulations as examined above that may hinder the freedom of association and assembly, which are not in accordance with the Constitution.

\section{B. Freedom of Opinion, Speech and Expression}

One of the civil and political rights, that laid the groundwork for the most cases filed with the Constitutional Court, relates to the freedom of opinion, speech and expression. Motivated by political and social change after the authoritarian regime was overthrown in 1998, guarantees for freedom of opinion, speech and expression, contained in Article 28 and Article 28E(3) of the Constitution, are used as the basis for reviewing laws considered to restrict these freedoms.

\section{Pornography Law case}

Another interesting decision that attracted public attention was the controversial Pornography Law (2009) case. ${ }^{21}$ In its petition, the applicants argued that the provisions in the Pornography Law restricted the freedom of expression by limiting the rights of indigenous peoples to express their cultural identity. In addition, they believed the formulation contained in the Pornography Law is ambiguous and open to multiple interpretations, leading to problems in its application, particularly in criminalising women who often become the object of pornography.

In its decision, the Constitutional Court rejected the petition using the provisions set forth in Article 28J of the Constitution. The Court found that restrictions on rights

\footnotetext{
19 Ibid., pp. 127-8.

${ }^{20}$ Constitutional Court of Republic of Indonesia, "Decision No. 3/PUU-XII/2014."

${ }^{21}$ Constitutional Court of Republic of Indonesia, "Decision No. 10-17-23/PUU-VII/2009”.
} 
and freedoms are acceptable in a democratic society when based on laws in accordance with considerations of morality, religious values, security and public order. However, the Court made an important constitutional interpretation by stating that there are five areas that cannot be categorised as pornography, namely arts, literature, custom, science and sport.

As long as they are drawings, sketches, illustrations, photographs, texts, voices, sounds, moving pictures, animations, cartoons, conversations, gestures, or other forms of messages through various forms of communication media and/or performances in public, in the framework of art, literature, custom, science and sports, then it is not an act of pornography as referred to in the [Pornography] Law.

\section{Leste Majeste and Hate Showing cases}

Several provisions in the Criminal Code were also deemed to restrict the freedoms of speech and expression. In the Leste Majeste (2006) case filed by Eggi Sudjana and Pandapotan Lubis, ${ }^{22}$ the Constitutional Court invalidated Article 134, Article 136 bis and Article 137 of the Criminal Code that regulated specific defamations against the president and vice-president. The Court ruled that the provisions are incompatible with the freedom of speech and expression guaranteed by Article 28 and Article $28 \mathrm{E}(2)$ and (3) of the Constitution. According to the Court, these provisions were used to protect the Dutch colonial rule. Additionally, these provisions were commonly used by law enforcements to silence protest. Hence, the freedom of speech and expression may be violated. ${ }^{23}$ Therefore, based on the rule of law and democratic principles adopted in Indonesia today, the Court declared that the three provisions shall not be applied because it could create legal uncertainty and multiple interpretations as to whether or not a protest is a statement of opinion or defamation against the president and/or vice-president.

Furthermore, Article 154 and Article 155 of the Criminal Code, relating to the expression of hostility, hatred or contempt against the Government of Indonesia, were also revoked by the Constitutional Court in the Hate Showing (2007) case filed by Panji Utomo. ${ }^{24}$ According to the Court, these criminal provisions, known as haatzai artikelen or 'rubber article', created a tendency for abuse of power because it can easily be interpreted according to the interests of the ruling power. ${ }^{25}$ Therefore, the Court ruled that the provisions are contrary to the freedom of speech and expression as guaranteed by the Indonesian Constitution.

\section{Incitement and Defamation cases}

However, not all constitutional review cases related to the freedom of opinion, speech and expression, as contained in the Criminal Code, were granted by the Constitutional Court, such as in the Incitement (2009) case. ${ }^{26}$ Rizal Ramli, an Indonesian politician and prominent economist, lodged a constitutional review of Article 160 of the Criminal Code related to an act of incitement in public because the provision could be used by the government to arrest any person who criticises the government. ${ }^{27}$ In

${ }^{22}$ Constitutional Court of Republic of Indonesia, “Decision No. 013-022/PUU-IV/2006."

${ }^{23}$ Ibid., p. 60.

${ }^{24}$ Constitutional Court of Republic of Indonesia, "Decision No. 6/PUU-V/2007."

${ }^{25}$ Ibid., p. 77.

${ }^{26}$ Constitutional Court of Republic of Indonesia, “Decision No. 7/PUU-VII/2009."

${ }^{27}$ Article 160 of the Criminal Code states, "Any person who orally or in writing publicly incites a punishable act, a violent action against the public authority or any other disobedience, either to a statutory provision or to an official order issued under a statutory provision, shall be punished by a maximum im- 
its decision, the Constitutional Court stated that the substance of Article 160 is still in line with the rule of law because it contains the principle of universal norms, which prohibits inciting people to commit criminal acts. However, the Court declared Article 160 to be conditionally constitutional, meaning it would remain constitutional as long as it interpreted as material offenses which consider the result of criminal acts based on prohibited acts.

Moreover, in the Defamation (2008) case $^{28}{ }^{28}$ Risang Bima Wijaya and Bersihar Lubis applied for constitutional review of provisions relating to defamation in the Criminal Code considered contrary to the freedom of thoughts, conscience, speech and communication. In addition, the applicants argued that the provision was easily misused by those who do not like the freedom of thought and opinion, freedoms of expression and freedom of the press. In its legal reasons, the Constitutional Court stated that the Indonesian Constitution guarantees the rights and freedoms mentioned by the applicants, so the state must protect them.

Nevertheless, the state, at the same time, is also obliged to protect the constitutional rights of others, equal to the applicant's rights, as guaranteed by Article 28G of the Constitution and international law under the rights to honour and dignity. According to the Court, under an obligation to protect the constitutional rights of others, the state is allowed to make restrictions as expressly stated in Article 28J(2) of the Constitution. Interestingly, the Constitutional Court considered the legal issue raised by the applicants as concerning the implementation of the provision in question. Thus, the Court argued that it was more closely related with a constitutional complaint case, a jurisdiction that is not owned by the Constitutional Court, rather than a constitutional review case $^{29}$

Similar decisions by the Constitutional Court can also be found in the Online Defamation cases in 2008 and $2009 .{ }^{30}$ The difference is the provisions reviewed were related to actions conducted in cyberspace. In both cases, the applicants, consisting of journalists, human rights activists and NGOs, filed a constitutional review of Article 27(3) of the Information and Electronic Transactions (ITE) Law, considered contrary to the principles of the rule of law and the spirit of democracy that hold freedom of the press and freedom of expression as basic human rights. ${ }^{31}$ The Constitutional Court ruled that the article is constitutional on the grounds that it is still necessary for balancing between freedom of expression and the rights to honour and dignity of other people, equally guaranteed by the Constitution and international laws, inter alia, in Article 12 of the UDHR and Article 17 and Article 19 of the ICCPR.

\section{Analysis}

Based on several decisions relating to the freedom of opinion, speech and expression, as discussed above, it can be argued the decisions made by the Constitutional Court determine the direction and development of freedom of opinion, speech and expression in Indonesia, as an emerging country. In the Leste Majeste (2006) case and the Hate Sowing (2007) case, which place citizens in opposition to the government,

prisonment of six years or a maximum fine of three hundred Rupiahs."

${ }^{28}$ Constitutional Court of Republic of Indonesia, “Decision No. 14/PUU-VI/2008."

${ }^{29}$ Ibid., p. 275.

${ }^{30}$ Constitutional Court of Republic of Indonesia, "Decision No. 50/PUU-VI/2008”; Constitutional Court of Republic of Indonesia, "Decision No. 2/PUU-VII/2009."

31 Article 27(3) of the ITE Law states, "Any Person who knowingly and without authority distributes and/or transmits and/or causes to be accessible Electronic Information and/or Electronic Records with contents of affronts and/or defamation." 
the Constitutional Court made strong decisions by invalidating several provisions in the Criminal Code considered as hampering the development of democracy in Indonesia. Nevertheless, in the Defamation case and the Online Defamation cases, which concern the rights and freedoms of a person in relationship to the rights and freedoms of others, the Constitutional Court tends to make compromises to maintain harmony and balance between the interests of law and the rights and freedoms of the diverse parties in the community.

Another important point to be underlined is that the Constitutional Court also confirmed that restrictions on the freedom of opinion, speech and expression are permitted by the Constitution and international laws on the grounds "to guarantee the recognition and the respect for the rights and freedoms of others and to fulfil fair demand in accordance with the considerations of morality, religious values, security and public order in a democratic society."32 In the future, the debate on freedom of opinion, speech and expression will remain important in protecting civil and political rights in Indonesia. Special attention should be given to provisions contained in the ITE Law. With the rapid development of information, communication, and technology, the implementation of the ITE Law has led to many people being charged with defamation $^{33}$

\section{Freedom of Religion}

Indonesian society adhere to different religions, including Islam, Catholicism, Protestantism, Hinduism, Buddhism and Confucianism. Interestingly, although Indonesia is a country with the largest Muslim population in the world with $207,176,162$ people (87.21\%),34 Indonesia is neither an Islamic state nor a state based on a particular religious ideology. In contrast to many other countries, one of the Indonesian core ideologies of Pancasila is 'belief in the One and Only God' (Ketuhanan Yang Maha Esa), contained in the fourth paragraph of the Preamble of the Constitution. The second paragraph specifically mentions the phrase, 'With the blessing of God the Almighty'. In addition, based on Article 24(2) of the Constitution, Indonesia has religious courts for Islamic citizens to settle certain cases.

Before the amendment of the 1945 Constitution, the provision on freedom of religion was only contained in Article 29(2). Currently, the freedom of religion is strengthened in a special chapter of Human Rights in Article 28E(1) and Article 28I(1) of the Constitution. Constitutional provisions on religion are not only related to the freedom of religion, but also concern the restriction of rights and freedoms that can be limited in accordance with religious values.

\section{Polygamy case}

The first case decided by the Indonesian Constitutional Court relating to the

${ }^{32}$ Indonesia, Undang-Undang Dasar Negara Republik Indonesia Tahun 1945 (Indonesian 1945 Constitution), art. 28J(2).

33 Indonesian and Communication Technology (ICT) Watch Indonesia reported that 71 people had faced defamation charges based on ITE Law since as of October 2014. See Bambang Muryanto, "ITE Law increasingly threatens press freedom," The Jakarta Post, November 17, 2014, http://www.thejakartapost. com/news/2014/11/17/ite-law-increasingly-threatens-press-freedom.html.

${ }^{34}$ Ministry of Religious Affairs of Republic of Indonesia, Laporan Tahunan Kehidupan Keagamaan di Indonesia Tahun 2013, [Annual report on Religious Life in Indonesia 2013] (Jakarta: Kementerian Agama, 2014). 
freedom of religion was the Polygamy (2007) case. ${ }^{35}$ An applicant, named M. Insa, reviewed the constitutionality of provisions in the Marriage Law because he considered them restrictive to his freedom of worship as a Muslim. The Indonesian Marriage Law recognises the principle of monogamy, while the practice of polygamy requires legal consent from the religious court with strict requirements. According to the applicant, these provisions violated his freedom of religion because polygamy is allowed by Islam ${ }^{36}$

The Constitutioal Court rejected the application. In deciding this case, apart from using provisions in the Constitution, the Court also used the verses of Al-Quran in providing legal reasons ${ }^{37}$ According to the Court, the provisions in the Marriage Law, which contain the reasons, conditions and procedures of polygamy, are solely an effort to ensure the fulfilment of rights for the first wife and other prospective wives who become the obligation of a husband ${ }^{38}$ The Court reasoned that the state, as the highest organisation in a community based on political consensus, is not only authorised to regulate, but also obliged, to ensure the realisation of justice through legal instruments under its control and enforcing it through the courts ${ }^{39}$

\section{Religious Court case}

In the Religious Court (2008) case $^{40}$ an applicant named Suryani lodged a constitutional review case concerning the religious court's jurisdiction limiting examinations for deciding and resolving cases for Muslims in the specific areas of marriage (perkawinan), inheritance (waris), wills (wasiat), gifts (hibah), endowments or waqf (wakaf), mandatoryalms (zakat), liablealms (infaq), voluntary alms (shadaqah) and the Shari'ah economy (ekonomi syari'ah). According to the applicant, the freedom of religion and worship has been limited by the state through the Religious Court Law. The applicant requested additional jurisdictions for the religious courts based on other Islamic laws, including Islamic criminal law (jinayah). The Constitutional Court found that the Religious Court Law did not diminish the freedom of religion and worship of the applicant, as guaranteed by the Constitution. The most interesting legal reason for rejecting the applicant's argument in this case was the Constitutional Court's explanation of the relationship between the state and religion in Indonesia.

The Court is of the opinion that the applicant's argument is not in accordance with the statesmanship view of Indonesia concerning the relationship between the state and religion. Indonesia is not a religion-based state which is solely based on one certain religion, neither is Indonesia a secular state which does not pay attention to religions and leaves the religious affairs totally to the individual and the people. Indonesia is a state based on the Almighty God which protects every adherent of religions to worship in accordance with his/her religions. ${ }^{41}$

The Constitutional Court also stated that:

\footnotetext{
${ }^{35}$ Constitutional Court of Republic of Indonesia, "Decision No. 12/PUU-V/2007."

${ }^{36}$ In general, there are three types of polygamy, namely polygyny, polyandry, and polyamory. The term of polygamy in this case is referred to polygyny which describes a husband with multiple wives. See James J. Ponzetti, "Polygamy" in Cultural Sociology of Divorce: An Encyclopedia, edited by Robert E. Emery (London: SAGE Publications, 2013), p. 981.

${ }^{37}$ See Nadirsyah Hosen, “The Constitutional Court and 'Islamic' Judges in Indonesia," Australian Journal of Asian Law Vol. 16 Issue 1 (2016): 6-7.

${ }^{38}$ Constitutional Court of Republic of Indonesia, “Decision No. 12/PUU-V/2007," pp. 97-98.

39 Ibid., p. 94.

${ }^{40}$ Constitutional Court of Republic of Indonesia, “Decision No. 19/PUU-VI/2008."

41 Ibid., p. 24.
} 
...If the problem of the imposition of Islamic law is related to the source of law, accordingly it can be said that Islamic law actually becomes the source of the national law, but Islamic law is not the only source of national law, because besides the Islamic law, customary law, and western law, as well as other sources of law traditions have also become sources of the national law. Therefore, Islamic law can become one of the material sources as the material of formal laws and regulations. Islamic law as a source of law can be used together with other sources of law, so that it becomes the material for the formation of laws and regulations to be applied as national law. ${ }^{42}$

\section{Blasphemy Law case}

The constitutional case that has attracted the most public attention, concerning the freedom of religion, was the Blasphemy Law (2010) case; ${ }^{43}$ not only because the case was complex, but also because it was highly sensitive as it directly related to religions. The applicants comprised seven human rights NGOs and several Muslim intellectuals, including former President Abdurrahman Wahid, better known as Gus Dur. They filed a constitutional review against Law Number 1/PNPS/1965 on Preventing the Abuse and Dishonouring of Religion (hereinafter, the Blasphemy Law) because it was deemed to cause religious discrimination, restrictions on religious interpretation, prohibition against someone's beliefs, criminalisation of religion and create legal uncertainty. This case presents important interpretations concerning limitations of state intervention on the freedom of religion in Indonesia. Thus, this case will be examined in more detail through the following four salient arguments.

First, the Constitutional Court held that the blasphemy provisions should include philosophical facets highlighting freedom of religion, as well as the juridical aspect, from the Indonesian perspective. According to the Court, religious practices in Indonesia differ from religious practices in other countries and cannot be equated. In addition, the principles of negara hukum (literally, law state) in Indonesia should not be the same as the principles of rechtsstaat and the rule of law. The Court reasoned that the principles of negara hukum must be seen from the perspective of the 1945 Constitution that places the Almighty God as the foundation of nation and the state through religious principles and values. Thus, the Constitutional Court ruled that Indonesia does not follow the concept of separation of state and religion, nor does it merely hold the principles of individualism and communalism. ${ }^{44}$

Second, the Constitutional Court confirmed that the Indonesian Constitution does not provide for the possibility of campaigning without holding a particular religion or promoting freedom without religion. In other words, the advocacy of atheism is indirectly prohibited, although no clear prohibition is stated within the law. Additionally, people are prohibited from insulting religious teachings, holy books that provide a source of religious belief and the name of God. According to the Court, these elements are the main differentiators between Indonesia and other western countries.

Third, the Constitutional Court reasoned that freedom of belief could not be restricted or prosecuted by any imposition. The Court reasoned that this freedom exists in people's minds and hearts through their beliefs. In this context, the Court defined it as a forum internum, unable to be restricted, but influenced by certain environments. In contrast, the freedom to express thoughts and attitudes related to

\footnotetext{
42 Ibid.

${ }^{43}$ Constitutional Court of Republic Indonesia, “Decision No. 140/PUU-VII/2009.”

${ }^{44}$ Ibid., p. 275.
} 
the relationship with others on religious matters, known as a forum externum, may be restricted by the state. ${ }^{45}$ According to the Court, the Blasphemy Law does not limit a person's beliefs (forum internum), but only limits the statement of thoughts and conscience in public (forum externum) that deviate from the principal teachings of religion professed in Indonesia, and the expression of a feeling or action that is essentially hostile, misused or blasphemous of a religion. ${ }^{46}$

Fourth, concerning religious interpretation, the Constitutional Court stated that, although the religious interpretation is part of the freedom of religion categorised as forum internum, it shall conform with the principal teachings of religion through correct methodology based on the relevant source of religious teaching according to the holy book. Thus, the Court stated that freedom to interpret a religion is not an absolute freedom. The Court stated that the interpretation, not based on a common methodology recognised by the adherents of a religion or the relevant sources of the holy book, would threaten public order if presented or performed in public. In this case, the Constitutional Court reasoned that such limitations can be carried out in accordance with Article 18 (3) of the International Covenant on Civil and Political Rights (1966) which states, "Freedom to manifest one's religion or beliefs may be subject only to such limitations as are prescribed by law and are necessary to protect public safety, order, health, or morals or the fundamental rights and freedoms of others." 47

Although the Constitutional Court held that the Blasphemy Law is still needed and does not conflict with human rights protection stipulated in the Constitution, yet the Court found that the Blasphemy Law should be formally and substantially revised to provide clearer interpretations of its practice. The Court addressed this recommendation to legislators through legislative review. It can be said that this decision is another compromise where the Court did not invalidate the Blasphemy Law, yet it did take into consideration the current relationship between the state and religion in Indonesia. In addition, the Constitutional Court suggested improving the Blasphemy Law through legislation in answer to doubts and concerns about the Blasphemy Law. Nevertheless, the Constitutional Court did not explain in detail which matters in the Blasphemy Law would have to be revised.

\section{Analysis}

Based on the three cases examined above, the Constitutional Court has given extensive interpretations on freedom of religion, particularly in the Blasphemy Law (2010) case. According to the Court, restriction on the basis of religious values, as mentioned in Article 28J(2) of the Constitution, is one way human rights may be restricted in Indonesia. The Court showed that this concept is different from Article 18 of the ICCPR, which does not include religious values as a basis for limiting freedom of individuals. ${ }^{48}$ However, despite the guarantee of freedom of religion since the reform era, there exist a growing number of cases brought to the ordinary courts based on the violations of the Blasphemy Law and Article 156a of the Criminal Code concerning to blasphemy of religion. Crouch noted that there were less than 10 cases of blasphemy during the New Order Era (1996-1998). Nevertheless, there were 47 cases in which 120 people were convicted under the Blasphemy Law during the Reform Era from

\footnotetext{
45 Ibid., p. 287.

46 Ibid., p. 288.

47 Ibid., p. 288-289.

48 Ibid., p. 275.
} 


\section{8 to $2012 .^{49}$}

The current condition regarding the freedom of religion in Indonesia has raised concern that the majority can obstruct religious freedom of minorities, both within the same religion or a different religion. This condition is exacerbated when law enforcement agencies are afraid to carry out their functions and obligations to protect the security and safety of all citizens, regardless of their religions or beliefs, from the threat of violence due to pressure by the majority power.

Regardless of the pros and cons in the Blasphemy Law cases, one thing that is agreed upon by all parties is that the Constitutional Court could be a forum for peaceful and open dialogue between the various parties, with different beliefs and views on the interpretation of freedom of religion. Indeed, the issues discussed were very sensitive and often triggered social conflict among the diverse religious adherents. By using the concept of a religious nation state ${ }^{50}$ Indonesia will continue to seek the best format for implementation and protection of religious freedom.

At the time of this writing, as suggested by the Constitutional Court, the Ministry of Religious Affairs is working on the Bill of Religious Harmony (Kerukunan Umat Beragama) in response to the Constitutional Court's recommendation to replace the Blasphemy Law, considered no longer in accordance with the development of society. In general, this Bill will regulate the protection of all religions and beliefs in Indonesia. However, the Bill also invites controversy among religious organisations and individuals who support or reject it. ${ }^{51}$ This indicates that the issues of religious freedom and its restriction will continue to be debated in Indonesia.

\section{Right to Life}

The constitutional debate over the death penalty has become an important issue in Indonesia related to the right to life. The Constitutional Court has decided two cases of constitutional review concerning the constitutionality of the death penalty.

\section{Death Penalty (2007) case}

The Indonesian Constitutional Court's decision on the constitutionality of the death penalty has attracted the most attention from the international community. In the Death Penalty (2007) case, $^{52}$ three Australian citizens involved in a drugs smuggling syndicate, known as 'the Bali 9', and two Indonesian nationals filed for constitutional review of the death penalty contained in the Narcotics Law. According to the applicants, the imposition of the death penalty was contrary to Article 28A and Article 28I(1) of the Constitution, which states that the right to life is a human right cannot be reduced under any circumstances.

The right to life, the right not to be tortured, the right of freedom of thoughts and conscience, the right to have a religion, the right not to be enslaved, the right to be

49 - Discussion on this issue, see Melissa A. Crouch, "Law and Religion in Indonesia: The Constitutional Court and the Blasphemy Law," Asian Journal of Comparative Law Vol. 7 Issue 1 (2012): 1, accessed November 10, 2015, doi: http://dx.doi.org/10.1515/1932-0205.1391.

50 Moh. Mahfud MD., "Konstitusi Negara," Orientation Event of the DPR Members (PDI-P Faction, Jakarta, September 8, 2009), p. 2.

51 “Ministry Prepares Religions' Followers Protection Bill," The Jakarta Post, June 16, 2015, accessed November 12, 2015, http://www.thejakartapost.com/news/2015/06/16/ministry-prepares-religionsfollowers-protection-bill.html.

52 Constitutional Court of Republic of Indonesia, “Decision No. 2-3/PUU-V/2007." 
recognised as a person before the law, and the right not to be prosecuted under retroactive law are human rights that cannot be reduced under any circumstances. ${ }^{53}$

The applicants based their arguments on the UDHR and Article 6 of the ICCPR, as well as several other conventions, such as the current trend in the international community to abolish the death penalty. According to these arguments, the death penalty is contrary to the philosophy of punishment in Indonesia and the deterrent effect of the death penalty in reducing the number of criminal acts is doubtful.

The Constitutional Court found that foreign nationals do not have the legal standing to file a case with the Indonesian Constitutional Court. Given that two of the applicants were Indonesian citizens, however, the Constitutional Court examined the main case and provided legal reasons. The main constitutional question in this case was whether or not human rights, as set forth in Article 28(1) of the Constitution known as non-derogable rights, are absolute rights that cannot be reduced under any circumstance. Based on the original intent of Article 28J of the Constitution, the Court reasoned that everyone has the obligation to respect other's rights in exercising their own human rights, so that human rights, according to the Indonesian Constitution, are not absolute.

In other words, human rights are subject to limitation as far as the restrictions are established by laws and fulfil fair demand in accordance to Article 28J. The Court referred its arguments to international legal instruments, in particular to Article $6(2)$ of the ICCPR that explains that the right to life is not absolute, but it can still be applied to 'the most serious crimes in accordance with the law in force at the time of the commission of the crime...' Indeed, Indonesia is not a State party to the Second Optional Protocol of the International Covenant on Civil and Political Rights, which aims to abolish the death penalty.

The next question is whether or not drug crimes constitute one of the most serious crimes and deserving of the death penalty. The Constitutional Court reasoned that Indonesia is obliged to implement international law as a State party to the United Nations Convention against Illicit Traffic in Narcotic Drugs and Psychotropic Substances (1988). According to the Court, the Narcotics Law imposes the death penalty for limited criminal acts, considered in accordance with Article 3(6) of the Convention, with the objective 'to maximize the effectiveness of law enforcement measures in respect of those offences, and with due regard to the need to deter the commission of such offences.'

Thus, the Court has included the possession of narcotics as one of the most serious crimes, along with the crime of genocide and crimes against humanity, because these crimes 'adversely affect the economic, cultural and political foundation of society,' and also cause 'a danger of incalculable gravity. ${ }^{54}$ Therefore, the Court ruled that the death penalty provisions in the Narcotics Law remain constitutional.55 However, the decision was not unanimous. One Constitutional Justice argued that foreign nationals should be given legal standing; another Constitutional Justice said that the

53 Indonesia, Undang-Undang Dasar Negara Republik Indonesia Tahun 1945 (Indonesian Constitution of 1945), art. 28I(1).

${ }^{54}$ Constitutional Court of Republic of Indonesia, “Decision No. 2-3/PUU-V/2007,” p. 426.

${ }^{55}$ Natalie Zerial argued that this decision is based on the balance between the rights of individuals and the public welfare that become the characteristic of human rights debate in Asia. See Natalie Zerial, "Decision No. 2-3/PUU-V/2007 [2007] (Indonesian Constitutional Court)," Australian International Law Journal Year 2007 Vol. 14 (2007), p. 217. 
death penalty provisions in the Narcotics Law were unconstitutional; and two other Constitutional Justices argued that foreign nationals should have legal standing and that the death penalty provisions were contrary to the 1945 Constitution. ${ }^{56}$

\section{Death Penalty (2012) case}

The above decision only concerned the constitutionality of the death penalty provisions in the Narcotics Law, but it did not address the Criminal Code or other laws. Therefore, the constitutionality of other death penalty provisions can still be reviewed, or even invalidated by the Constitutional Court. However, the Court did not use the same standards in assessing the criteria of the most serious crimes in the Death Penalty (2012) case. ${ }^{57}$ Two applicants filed a constitutional review case regarding the death penalty provision contained in the Criminal Code. They had been sentenced to death based on Article 364(4) of the Criminal Code concerning the crime of theft accompanied by force or threat of force resulting in serious physical injury or death. According to the applicants, such crime could not be categorised as the most serious crime, so the death penalty provision were contrary to the Constitution.

Without explaining in detail or referring to any international law instrument stating a crime of theft accompanied with violence is a form of the most serious crime, the Constitutional Court simply referred to the previous decision in the Death Penalty (2007) case and declared that the imposition of the death penalty for such crime is constitutional. The Court only provided one paragraph of legal reason to explain why such crime should be categorised as one of the most serious crimes.

According to the Court, the crime of theft, with violence resulting in the death of the victim, is a serious crime (the most serious crime) because its commission causes the same psychological effects [as drug crimes do], thus it is reasonable that the punishment be the same. The punishment for these two crimes is expected to create deterrent effects and prevention of crimes, both for the accused and society. ${ }^{58}$

\section{Analysis}

The Constitutional Court decisions related to the right to life have created pros and cons. Human rights activists are the loudest group opposing the death penalty. Based on the two cases above, the Constitutional Court should be more selective in assessing criminal acts categorised as the most serious crime. The arguments regarding what criteria distinguish the most serious crimes should not be based on national laws and psychological assumptions only, but also held to a standard based on international law. A violent crime of theft, however, cannot be equated with drug crimes, genocide crimes or crimes against humanity classified as the most serious crime. In the future, the Constitutional Court will be faced with different applications for constitutional review of death penalty provisions, which are spread throughout several laws, such as in the Anti-Corruption Law, the Anti-Terrorism Law and the Criminal Code, e.g., crimes against state security or friendly countries, aircraft piracy and premeditated murder.

Furthermore, the Constitutional Court affirmed that the right to life can be limited under Article 28J of the Constitution, so that the death penalty can be imposed only on the most serious crimes. However, it is clear that the Constitutional Court

${ }^{56}$ See dissenting opinions of the Constitutional Justices, Constitutional Court of Republic Indonesia, “Decision No. 2-3/PUU-V/2007," pp. 434-471.

${ }^{57}$ Constitutional Court of Republic of Indonesia, "Decision No. 15/PUU-X/2012."

${ }^{58}$ Ibid., pp. 19-20. 
is oversimplifying in applying the standards or criteria for the most serious crime, as seen in the Constitutional Court decisions in the Death Penalty cases in 2007 and 2012. In this context, the Court should not use the same legal reasons for different types of crimes.

\section{E. Due Process of Law}

Another category pertaining to the civil and political rights, which is often used as the basis for constitutional review, is due process of law. However, the Indonesian Constitution does not explicitly express any constitutional guarantee on due process of law. A provision relating to due process of law is contained in Article 28D(1) of the Constitution, which reads, 'Every person shall have the right to the recognition, guarantee, protection and legal certainty of just laws as well as equal treatment before the law.' Therefore, it can be said that the Constitutional Court interprets the human rights more extensively than what is written explicitly in the Constitution.

\section{Broadcasting Law case}

In the Broadcasting Law (2003) case, ${ }^{59}$ the Constitutional Court used the principle of due process of law for the first time to strike down a provision in the Broadcasting Law, obliging broadcasters to make corrections if the content is refuted. The Court reasoned that this provision contains an assumption that any denial or refutation means that a broadcast is definitely wrong, thus violating the principle of presumption of innocence. According to the Court, this provision can be interpreted as a violation of due process of law. ${ }^{60}$ The Constitutional Court referred to the principle of due process of law based on the conception of rule of law or negara hukum (law state) adopted by Indonesia, as stated in Article 1(3) of the Constitution which says, "The state of Indonesia is a law state."

\section{Bibit and Chandra case}

In the Bibit and Chandra (2009) case, ${ }^{61}$ the Constitutional Court examined the constitutionality of provisions in the Corruption Eradication Commission (KPK) Law which regulate that KPK Commissioners may be dismissed if they are named as defendants of a criminal case. In its legal reasons, the Constitutional Court emphasised the importance of the principle of due process of law as fundamental rights that must be protected by the state.

...due process of law is a principle which is fundamental and constitutional guarantees that all legal processes must be fair (honest) where people should be informed about the presence of a legal process against them and be granted a right for them to be heard before taking a decision on deprivation of their rights, freedoms and properties. Every person should not be deprived of the right to life, freedoms, properties and other rights without notice and opportunity to defend themselves. ${ }^{62}$

The Constitutional Court reasoned that the provision had violated the presumption of innocence and negated the principle of due process of law that requires a fair trial, just and impartial..$^{63}$ However, the Constitutional Court made a conditionally

\footnotetext{
${ }^{59}$ Constitutional Court of Republic of Indonesia, "Decision No. 005/PUU-I/2003".

${ }^{60}$ Ibid., pp. 83-84.

${ }^{61}$ Constitutional Court of Republic of Indonesia, “Decision No. 133/PUU-VII/2009.”

${ }^{62}$ Ibid., p. 68.

${ }^{63}$ The assertion on the right to presumption of innocence and due process, not expressly contained in
} 
unconstitutional decision. It means that the provision is unconstitutional unless it is interpreted that KPK Commissioners shall be dismissed after having a binding court decision.

\section{Book Banning case}

The Constitutional Court's decisions relating to the due process of law can also be found in the Book Banning (2010) case. ${ }^{64}$ Based on Law No. 4/PNPS/1963, the Attorney General has an authority to ban a book or to seize printed materials if its/ their contents can interfere public order. According to the Constitutional Court, it is absolutely necessary to implement the due process of law through the judicial system's law enforcement process. If there is an act categorised as an unlawful act, such as a book banning, then the decision must be made only after court hearings. In other words, an institution cannot declare a book banning without a court ruling. Although such restrictions are allowed by the Indonesian Constitution, the Constitutional Court found that restrictions on human rights without due process of law is clearly not intended in the scope of restrictions on rights and freedoms as referred to Article 28J(2) of the Constitution. ${ }^{65}$

\section{Pre-trial case}

A more comprehensive argument concerning the general principles of negara hukum, characterised by due process of law guaranteed in the Constitution, can be found in the Pre-trial (2014) case. ${ }^{66}$ According to the Constitutional Court, the other principles of negara hukum are recognition, guarantee of protection, a fair legal certainty and equal treatment before the law. Therefore, the Court confirms that due process of law is the embodiment of the human rights recognition in a criminal justice system and must be upheld by all parties, especially by law enforcement agencies. 67 In addition, the Court expressly stated that the Indonesian Criminal Procedure Law had not fully implemented the principles of due process of law. ${ }^{68}$

In this statement, the Court referred to the weakness of pre-trial (praperadilan) jurisdictions the authority of which is limited to the legality of an arrest, detention, termination of investigation or prosecution as well as the demand for compensation and/or rehabilitation for a person whose criminal case is terminated during investigation or prosecution. ${ }^{69}$ Therefore, the Court tried to overcome this problem by expanding the jurisdictions of pre-trial to include the determination of suspects, searches and seizure for objects examined in a pre-trial. According to the Court, these objects should also be protected through a legal mechanism in a pre-trial.

\section{Analysis}

Referring to the four different decisions above, it could be argued that the principle of due process of law has been recognised as one of the fundamental rights in Indonesia based on the interpretations made by the Constitutional Court on the

the Constitution, is also made by the US Supreme Court and the Australian High Court. See Anthony Gray, "Constitutionally Protecting the Presumption of Innocence," University of Tasmania Law Review Vol. 1 Issue 1 (2012): 140-141.

${ }^{64}$ Constitutional Court of Republic of Indonesia, “Decision No. 6-13-20/PUU-VIII/2010.”

65 Ibid., p. 242.

${ }^{66}$ Constitutional Court of Republic of Indonesia, “Decision No. 21/PUU-XII/2014."

${ }^{67}$ Ibid., p. 96.

68 Ibid., p. 103-104.

69 Indonesia, Undang-Undang tentang Hukum Acara Pidana (Law regarding Criminal Procedure), UU No. 8 Tahun 1981, LN No. 76 Tahun 1981 (Law Number 8 of 1981, SG. No. 76 of 1981), art. 77. 
concept of negara hukum contained in Article 1(3) of the Constitution. ${ }^{70}$ Given that the Indonesian criminal justice system still has many problems, in which it still uses the Criminal Code created during the Dutch colonial government, the implementation of the due process of law becomes very important in dealing with criminal cases.

In this context, the Constitutional Court may serve as the last bastion for criminal cases on the violation of human rights, in particular the principle of due process of law. However, the Constitutional Court's jurisdiction is limited to the review of abstract norms, so the Constitutional Court cannot directly examine concrete cases under the criminal justice system.

\section{CONCLUSION}

There has been progressive development concerning guarantee of human rights in the Indonesian Constitution since pre-independence. In the original 1945 Constitution, there were only seven provisions related to human rights. Drastic changes occurred after President Soeharto fell from power in 1998. Almost all provisions of human rights contained in the Universal Declaration of Human Rights (UDHR) were incorporated into the amended Indonesian Constitution. Presently, the Indonesian Constitution has a special chapter on Human Rights, contained in Article 28A to Article 28J. This chapter can be said to be a constitutional bill of rights.

However, the implementation and protection of those human rights are subject to restrictions according to Article 28J(2) of the Constitution. Although Article 28I(1) of the Constitution contains rights that cannot be limited under any circumstances, known as non-derogable rights, such as the right to life, Article 28J(2) becomes a key provision to limit those rights. According to the Indonesian Constitution, a person's human right can be restricted solely to protect the rights and freedoms of others based on moral considerations, religious values, security and public order in a democratic society.

Moreover, though the Indonesian Constitution recognises the principles of human rights as universal, their exercise is designed to adapt and to consider local values. This article shows that it is the main cause for the emergence of vigorous debates regarding the protection of human rights in Indonesia, in particular the difference of paradigms towards the exercise of human rights from western perspectives, which generally do not take into account religious values and local norms. The major problem in considering these values is that the implementation is often highly subjective and understood differently from one person to another.

In reviewing the constitutionality of laws relating to civil and political rights, the Indonesian Constitutional Court often uses the provisions contained in the constitutional bill of rights as its basis. Based on the discussion of various decisions in this article, it can be concluded that the Constitutional Court's contribution to the protection of civil and political rights in Indonesia is significant. The citizens now have a legal mechanism to protect their civil and political rights that never existed prior to the reform. Additionally, the Court in several cases also interprets other civil and political rights that must be protected for the citizens, although it is not stated explicitly in the Constitution, such as due process of law. In short, the

70 The Constitutional Court defines three main characteristics of a democratic constitutional state: (1) supremacy of law; (2) equality before the law; and (3) due process of law. See Constitutional Court of Republic of Indonesia, "Decision No. 14-17/PUU-V/2007." 
role played by the Constitutional Court has taken a step forward for human rights in Indonesia. Nonetheless, there are still some rights and freedoms that are considered not protected optimally by the Constitutional Court, particularly on the freedom of opinion, the right to life and the freedom of religion.

Furthermore, the Constitutional Court has limited power only to review the constitutionality of national law, which presents a weakness in its system of protecting fundamental rights and freedom of citizens. Indeed, potential violations of the human rights not only occur in national laws, but often originate from regulations and decisions made by both the central or regional governments and by public authorities. Due to the limitations of jurisdiction, the Constitutional Court is silent about these problems.

\section{Bibliography}

\section{Legal documents}

Indonesia. Keputusan Presiden tentang Dekrit Presiden Republik Indonesia/Panglima Tertinggi Angkatan Perang tentang Kembali kepada Undang-Undang Dasar 1945 (Decree of the President of the Republic of Indonesia/Supreme Commander of the War Armed Forces on the Return to the 1945 Constitution). Dekrit Presiden No. 150 Tahun 1959, LN No. 75 Tahun 1959 (Presidential Decree No.150 of 1959, SG No. 75 of 1959).

- - - Undang-Undang tentang Hukum Acara Pidana (Law regarding Criminal Procedure). UU No. 8 Tahun 1981, LN No. 76 Tahun 1981 (Law No. 8 of 1981, SG. No. 76 of 1981).

-_- Undang-Undang Dasar Negara Republik Indonesia Tahun 1945 (Indonesian 1945 Constitution ).

-_- Undang-Undang Dasar Sementara Republik Indonesia (Provisional 1950 Constitution).

United Nations. International Covenant on Civil and Political Rights (1966).

Constitutional Court of Republic of Indonesia. "Decision No. 005/PUU-I/2003."

- - - "Decision No. 013-022/PUU-IV/2006."

- ——. "Decision No. 2-3/PUU-V/2007."

—_—. "Decision No. 6/PUU-V/2007."

-——. "Decision No. 12/PUU-V/2007."

———. "Decision No. 14-17/PUU-V/2007."

———. "Decision No. 14/PUU-VI/2008."

———. "Decision No. 19/PUU-VI/2008."

———. "Decision No. 50/PUU-VI/2008."

———. "Decision No. 2/PUU-VII/2009."

———. "Decision No. 7/PUU-VII/2009."

———. "Decision No. 10-17-23/PUU-VII/2009."

———. "Decision No. 133/PUU-VII/2009."

———. "Decision No. 140/PUU-VII/2009."

——_. "Decision No. 6-13-20/PUU-VIII/2010."

- ——. "Decision No. 15/PUU-X/2012."

-_—. "Decision No. 82/PUU-XI/2013." 
. "Decision No. 3/PUU-XII/2014."

. "Decision No. 21/PUU-XII/2014."

\section{Books}

Asshiddiqie, Jimly. The Constitutional Law of Indonesia. Singapore: Sweet \& Maxwell, 2009.

Butt, Simon. The Constitutional Court and Democracy in Indonesia. Leiden: Brill, 2015. and Tim Lindsey. The Constitution of Indonesia: a Contextual Analysis. Oxford: Hart Publishing, 2012.

Dobinson, Ian and Francis Johns. "Qualitative Legal Research" in Research Methods for Law. Edited by Mike McConvile and Wing Hong Chui. Edinburgh: Edinburgh University Press, 2007.

Garner, Bryan A. Black's Law Dictionary. Ninth Ed. St. Paul, MN: Thomson Reuters, 2009.

Ginsburg, Tom. Judicial Review in New Democracies: Constitutional Courts in Asian Cases. New York: Cambridge University Press, 2003.

Harding, Andrew and Peter Leyland. Eds. Constitutional Courts: A Comparative Study. London: Wildy, Simmonds \& Hill, 2009.

Hutchinson, Terry. Researching and Writing in Law. New South Wales: Lawbook, 2010.

Joseph, Sarah and Melissa Castan. The International Covenant on Civil and Political Rights: Cases, Materials, and Commentary. Oxford: Oxford University Press, 2013.

Mahkamah Konstitusi Republik Indonesia. Naskah Komprehensif Perubahan UndangUndang Dasar Negara Republik Indonesia Tahun 1945. [Comprehensive Draft on Amendment of the 1945 Constitution of the Republic of Indonesia]. Jakarta: Sekretaris Jenderal dan Kepaniteraan MKRI, 2010.

Majchrzak, Ann. Methods for Policy Research. Thousand Oaks, CA: SAGE Publications, 1984.

Ministry of Religious Affairs of Republic of Indonesia. Laporan Tahunan Kehidupan Keagamaan di Indonesia Tahun 2013. [Annual report on Religious Life in Indonesia 2013]. Jakarta: Kementerian Agama, 2014.

Ponzetti, James J. "Polygamy" in Cultural Sociology of Divorce: An Encyclopedia. Edited by Robert E. Emery. London: SAGE Publications, 2013.

Sweet, Alec Stone. "Constitutional Courts" in Oxford Handbook of Comparative Constitutional Law. Edited by Michel Rosenfeld and Andras Sajo. Oxford: Oxford University Press, 2012.

Yamin, Muhammad. Naskah Persiapan Undang-Undang Dasar 1945. [Preparatory Draft of the 1945 Constitution]. Jakarta: Prapanjta, 1959.

___. Proklamasi dan Konstitusi Republik. Jakarta: Ghalia Indonesia, 1982.

\section{Articles}

Crouch, Melissa A. "Law and Religion in Indonesia: The Constitutional Court and the Blasphemy Law." Asian Journal of Comparative Law 7, issue 1 (2012): 1-46. Accessed on November 10, 2015. doi: http://dx.doi.org/10.1515/19320205.1391.

Gray, Anthony. “Constitutionally Protecting the Presumption of Innocence." University of Tasmania Law Review 1, issue 1 (2012): 132-154

Halfpenny, Peter. "The Analysis of Qualitative Data." The Sociological Review Vol. 27, issue 4 (1979): 799-827. Accessed on September 12, 2015. doi: 10.1111/j.1467954X.1979.tb00361.x. 
Horowitz, Donald L. “Constitutional Courts: A Primer for Decision Makers.” Journal of Democracy 17, issue 4 (2006): 125-137. Accessed on November 21, 2015. doi: http://dx/doi.org/10.1353/jod.2006.0063.

Hosen, Nadirsyah. "The Constitutional Court and 'Islamic' Judges in Indonesia." Australian Journal of Asian Law 16, issue 1 (2016): 1-11.

Mahfud MD, Moh. "Konstitusi Negara." Orientation Event of the DPR Members. PDI-P Faction, Jakarta, September 8, 2009.

Patrono, Mario. "The Protection of Fundamental Rights by Constitutional Courts - A Comparative Perspective." Victoria University of Wellington Law Review 21, issue 2 (2000): 401-426.

Zerial, Natalie. "Decision No. 2-3/PUU-V/2007 [2007] (Indonesian Constitutional Court)." Australian International Law Journal Year 200. 14 (2007): 217-226.

\section{Websites}

Mahkamah Konstitusi Republik Indonesia (Indonesian Constitutional Court). "Rekapitulasi Perkara." ["Case recapitulation."] http://www. mahkamahkonstitusi.go.id/index.php?page=web.Beranda. Accessed on 10 November 2015.

'Ministry Prepares Religions' Followers Protection Bill'. The Jakarta Post. June 16, 2015. http://www.thejakartapost.com/news/2015/06/16/ ministry-preparesreligions-followers-protection-bill.html. Accessed November 12, 2015.

Muryanto, Bambang. "ITE Law increasingly threatens press freedom." The Jakarta Post, November 17, 2014, http://www.thejakartapost.com/news/2014/11/17/itelaw-increasingly-threatens-press-freedom.html. 